\title{
Awareness of visceral leishmaniasis and its relationship to canine infection in riverside endemic areas in Northeastern Brazil
}

\author{
Kalidia Felipe de Lima Costa[1], Sthenia Santos Albano Amóra ${ }^{[1],[2],}$ \\ Camila Fernandes de Amorim Couto ${ }^{[1]}$, Celeste da Silva Freitas de Souza ${ }^{[3]}$, \\ Luanna Fernandes Silva ${ }^{[1]}$, Luiz Ney $d^{\prime E s c o f f i e r}{ }^{[3]}$, Maressa Laíse Reginaldo de Sousa ${ }^{[1]}$ \\ and Thais Aparecida Kazimoto ${ }^{[1]}$
}

[1]. Programa de Pós-Graduação em Ambiente, Tecnologia e Sociedade, Universidade Federal Rural do Semi-Árido, Mossoró, RN. [2]. Comissão Nacional de Saúde Pública Veterinária, Conselho Federal de Medicina Veterinária, Brasília, DF. [3]. Laboratório de Imunomodulação e Protozoologia, Instituto Oswaldo Cruz, Fundação Oswaldo Cruz, Rio de Janeiro, RJ.

\begin{abstract}
Introduction: An awareness of visceral leishmaniasis (VL) is necessary to encourage the population to participate in prevention and control in collaboration with more efficient, centrally organized health programs. The aim of this study was to evaluate the awareness of the riverside population regarding VL and the association between awareness and the prevalence of canine visceral leishmaniasis (CVL). Methods: In total, 71 people living in riverside areas in the City of Mossoró in State of Rio Grande do Norte participated of the study, and 71 dogs were tested for CVL by polymerase chain reaction (PCR). Association analysis of several variables related to knowledge of the riverside population regarding CVL positivity was performed, yielding odds ratios (OR) and 95\% confidence intervals (CI), and significance was determined using chi-square $(\chi 2)$ and Fisher's exact tests. Results: Among individuals whose dogs tested positive for CVL, $60 \%$ did not know the cure for CVL, and these subjects were three times more likely to have a dog test positive for CVL than those who were aware the cure for CVL. Knowledge of CVL cure was the only variable that remained in the logistic model after the successive removal of variables, with an adjusted OR of 3.11 (95\%CI: 1.1-8,799; $\mathrm{p}=0.032$ ). Conclusions: Insufficient awareness regarding VL in riverside areas with CVL-positive dogs was associated with increased rates of canine infection, which suggests that changes in habits and the adoption of attitudes and preventive practices may contribute to the control and prevention of this disease. This study reinforces the need to invest in better health education programs regarding VL.
\end{abstract}

Keywords: Visceral leishmaniasis. Risk factor. Owner. Dog. Leishmaniasis knowledge.

\section{INTRODUCTION}

Visceral leishmaniasis (VL) is a neglected disease despite its significant risk to public health. An estimated 200,000 to 400,000 new cases of VL occur worldwide each year, and more than $90 \%$ of these new cases occur in the following six countries: Bangladesh, Brazil, Ethiopia, India, South Sudan, and Sudan $^{1}$. Previously, VL was restricted to rural areas; however, with urbanization, the disease has expanded to urban areas. In Brazil, VL is found in all regions, although the most cases occur in the northeastern region ${ }^{2}$. Mossoró, located in the northeastern State of Rio Grande do Norte, is at the center of a VL epidemic

\footnotetext{
Address to: Msc. Kalidia Felipe de Lima Costa. Departamento de Agrotecnologia e Ciências Socias/UfERSA. Av. Francisco Mota 572, Bairro Costa e Silva, 59625-900 Mossoró, RN, Brasil.

Phone/Fax: 5584 3317-8306

e-mail: kalidialima@hotmail.com

Received 19 July 2014

Accepted 15 October 2014
}

and recorded 205 cases of human visceral leishmaniasis (HVL) between 2006 and 2012. During this period, 5,010 canine blood samples also tested positive for canine visceral leishmaniasis (CVL) in this city3.

Poor living conditions and poor sanitation favor human and canine infections by providing an environment that enables the survival and reproduction of the vector and facilitates transmission ${ }^{4-6}$. Previous studies have demonstrated the relationship between environmental variables and the density of vectors ${ }^{7,8}$; in particular, areas that flood during the rainy season due to their proximity to rivers are more vulnerable to VL because they have a higher insect density, particularly around homes?.

Thus, knowledge of CVL by pet owners would likely be associated with reduced canine infection with Leishmania infantum, as awareness of the disease would result in the population being more receptive to the use of insecticide sprays to control household sandflies ${ }^{10}$. In addition to knowledge regarding vector control measures to avoid exposure to infection from the bites of sandflies, knowledge on euthanasia, general pet care and management of the household environment is necessary ${ }^{11}$. 
It is essential to understand the knowledge, attitudes, and practices of the population with respect to VL because these factors, when satisfactory, contribute to the success of prevention and control programs through changes in behavior and more widespread participation ${ }^{12,13}$. The aim of this study was to evaluate the awareness of the riverside population of Mossoró, Rio Grande do Norte, regarding VL as well as the association between the awareness and prevalence of CVL.

\section{METHODS}

\section{Definition of the area and the sample}

Mossoró, located in the State of Rio Grande do Norte, Brazil, has a population of approximately 280,314 habitants. This city has an area of $2,099,333 \mathrm{~km}^{2}$ and is located $277 \mathrm{~km}$ from Natal, the state capital, and $42 \mathrm{~km}$ from the coast ${ }^{14}$. This western mesoregion has typical caatinga vegetation, and the climate is semiarid, with low and irregular rainfall and well-defined dry and rainy seasons ${ }^{15,16}$. This study included residents of the following well-defined areas along the Apodi-Mossoró River: Alto da Conceição, Ilha de Santa Luzia and Paredões. These areas were selected because they are the most affected by flooding during rainy periods, according to information obtained by the Civil Defense Department of Mossoró. The areas selected contain 477 residences. In addition, Mossoró has inadequate sanitation, hazardous environmental conditions and high rates of poverty, and these factors favor the occurrence of VL through the increased insect density during the rainy season, particularly around houses. Moreover, transmission of VL is favored by the absence of primary vegetation, the accumulation of organic material, and the presence of animals such as birds, swine and $\operatorname{dogs}^{8,9}$.

We visited all 477 households in the riverside areas to identify homes with dogs. However, to evaluate the awareness of the riverside population regarding VL and the association between awareness and the prevalence of CVL, only households with dogs were included in the study. The potential participants were informed of the terms and purpose of the study. Those who signed the informed consent form were interviewed, and those responsible for a dog or dogs were asked to participate in the CVL study by allowing the collection of a blood sample from the $\operatorname{dog}(\mathrm{s})$ for molecular analysis. In total, one individual was interviewed from each of 71 homes, and each residence had a dog that was tested, totaling 71 dogs.

\section{Awareness of visceral leishmaniasis}

To evaluate the awareness of VL, semi-structured interviews that were developed specifically for this research were conducted. These interviews addressed the socioeconomic profile of the interviewees and their awareness regarding the means of transmission, the most common symptoms of the disease, the means of diagnosis and treatment, the existence of a vaccine, and the means of prevention of VL in humans (HVL) and in dogs (CVL).

\section{Molecular diagnosis of canine visceral leishmaniasis}

Peripheral blood samples were collected from 71 dogs and sent to the Laboratório de Imunomodulação e Protozologia do Instituto Oswaldo Cruz - Fundação Oswaldo Cruz (Immunomodulation and Protozology Laboratory of the Institute Oswaldo Cruz FIOCRUZ) in Rio de Janeiro, Brazil for molecular analysis by polymerase chain reaction (PCR).

DNA extraction was conducted using the phenol-chloroform method, as described by Harris et a ${ }^{17}$. PCR was performed using the following primers for species-specific amplification of a 351bp fragment of kinetoplast DNA (kDNA) of Leishmania infantum: 5'- GCC CGC G(C/T)G TCA CCA CCA T - 3' and 3'- CGG GCG C(G/A)C AGT GGT GGT - 5 ${ }^{17}$.

\section{Statistical analysis}

The data were entered on a spreadsheet and transferred to Statistical Package for Social Sciences software (version 17.0, SPSS, Inc., Chicago, IL, USA) for subsequent coding and analysis. The associations of several variables with canine positivity were tested, yielding odds ratios (OR) and 95\% confidence intervals $(\mathrm{CI})$, and significance was determined using chi-square $(\chi 2)$ and Fisher's exact tests. The latter test was used when values were to occur with an expected frequency of less than five. A logistic regression model was developed to study, simultaneously, the factors involved in the prevalence of CVL positivity. For the analysis, we used variables with $\mathrm{p}$ values $<0.20$, as well as some that did not show significant differences if they were considered important factors associated with infection. We excluded variables with CIs that showed large-scale estimates of the ORs, as well as those that presented colinearities in the logistic model. Therefore, the analysis for the final model was formed from variables with a significance level of $p<0.10$, which were re-evaluated by successive removal each variable. At this stage, a significance level of $\mathrm{p}<0.05$ was used.

\section{Ethical considerations}

The survey was approved by the Comitê de Ética em Pesquisa, (Committee of Ethics and Research) of the Universidade do Estado do Rio Grande do Norte (Legal Opinion Number: 71259 and CAAE: 03692212.5.0000.5294) and by the Comissão de Ética no Uso de Animais, Commission of Ethics for the Usage of Animals of the Universidade Federal Rural do Semi-Árido (Legal Opinion Number: 61/2012, Process Number 23091.002189/212-41).

\section{RESULTS}

The PCR results showed that $39 \%(28 / 71)$ of the dogs tested positive for $L$. infantum DNA. Among the 71 interviewees, $79 \%(22 / 71)$ were female; $64 \%$ (18/71) had completed primary school; and $60 \%$ (18/71) had family incomes of more than three times the minimum wage. Age was identified as a risk factor, and this variable was used in the logistic model. Specifically, interviewees between 18 and 30 years of age or over 65 years of age had three times the risk of having a CVL-positive dog compared with those aged between 31 and 65 years (Table 1). Regarding transmission of the disease, among interviewees with positive dogs, 68\% (19/71) did not possess knowledge of VL transmission and had twice the risk for canine positivity than those who knew how VL is transmitted $(\mathrm{p}<0.2)$. 
Additionally, 61\% (17/71) of interviewees did not have knowledge of VL prevention, and we also observed a lack of awareness of HVL symptoms and treatment. Many interviewees were not aware of a vaccine or cure for HVL, although there was better awareness of CVL symptoms.

Among those with CVL-positive dogs, 60\% (15/71) did not know about cure for CVL, and these subjects had a three-fold greater risk of having CVL-positive dogs compared those who had knowledge of CVL cure. In the logistic regression analysis, only knowledge of CVL cure was kept in the logistic model after the successive removal of each variable, with an adjusted OR of 3.11 (95\% CI: 1.1- 8.799, $\mathrm{p}=0.032$ ) (Table 2).

\section{DISCUSSION}

\section{Factors associated with the population}

The education level of the interviewees with CVL-positive dogs was not associated with an increased risk of infection. However, in research conducted in Belo Horizonte, in the State of Minas Gerais, Brazil, the authors observed a correlation between a low educational level and an increased risk of VL; in particular, individuals who had never attended school had an eight-fold higher risk of infection ${ }^{13}$. In our study, there was a three-fold increased risk among interviewees with CVLpositive dogs, who were aged between 18 and 30 years or over 65 years, and canine infection was associated with less access to information regarding diseases such as VL and their preventive measures. This association may be due to restriction within domestic environments with inadequate health education.

\section{Factors associated with transmission and prevention}

Most of the interviewees had only vague knowledge of the mechanics of VL transmission. The interviewees were generally aware that transmission occurs through an insect bite; however, they failed to identify the sand fly as a vector. Similar results were observed in a survey conducted in Divinópolis, State of Minas Gerais, Brazil, in which approximately one-half of the population interviewed was unaware of how VL was transmitted, and only $29 \%$ knew of the necessity for an insect bite ${ }^{18}$.

The knowledge of the riverside population participating in this study regarding the mode of LV transmission showed an inverse relationship with canine infection. Lack of knowledge regarding the transmission of this disease influenced the occurrence of CVL in these areas, which may imply a lack of preventive measures. Such a lack of awareness regarding the transmission of $\mathrm{VL}$ and information regarding the vector responsible for the disease emphasizes the importance of disseminating transmission information, including the biological and ecological aspects of the vectors, to allow the community to participate in preventative measures ${ }^{19}$.

Previous studies performed in Mossoró reported the presence of the VL vector in different areas of the city throughout the year ${ }^{7}$. The riverside areas in this study included favorable conditions for sand flies and dogs infected with $L$. infantum; thus, we assumed that this population is vulnerable to $\mathrm{VL}$, as confirmed by previous surveys ${ }^{20,21}$.

TABLE 1 - Results of the association between canine visceral leishmaniasis and several variables regarding the population of riverside areas in Mossoró, State of Rio Grande do Norte, 2014.

\begin{tabular}{|c|c|c|c|c|c|c|}
\hline \multirow[b]{3}{*}{ Variable } & \multicolumn{3}{|c|}{ Canine visceral leishmaniasis } & \multirow[b]{3}{*}{ OR } & \multirow[b]{3}{*}{$95 \% \mathrm{CI}$} & \multirow[b]{3}{*}{$P$ value } \\
\hline & \multicolumn{2}{|c|}{ positive } & \multirow{2}{*}{$\frac{\text { negative }}{\mathrm{n}}$} & & & \\
\hline & $\mathrm{n}$ & $\%$ & & & & \\
\hline \multicolumn{7}{|l|}{ Gender } \\
\hline male & 6 & 21.4 & 9 & 1.03 & $0.322-3.299$ & 0.960 \\
\hline \multicolumn{7}{|l|}{ Age } \\
\hline between 18 and 30 years & 8 & 28.6 & 6 & 3.022 & $0.891-10.24$ & 0.069 \\
\hline$>65$ years & 5 & 17.8 & 3 & 3.778 & $0.798-17.887$ & 0.114 \\
\hline 31 to 54 years & 15 & 53.6 & 34 & 1 & - & - \\
\hline \multicolumn{7}{|l|}{ Education } \\
\hline$\geq$ elementary school & 18 & 64.3 & 28 & 0.9 & $0.329-2.458$ & 0.959 \\
\hline middle or high school & 10 & 35.7 & 14 & 1 & & \\
\hline
\end{tabular}

OR: odds ratio; 95\% CI: confidence interval 95\%. 
TABLE 2 - Results of the association between canine visceral leishmaniasis and several variables regarding the knowledge of the population of riverside areas in Mossoró, State of Rio Grande do Norte, 2014.

\begin{tabular}{|c|c|c|c|c|c|c|}
\hline \multirow[b]{3}{*}{ Variable } & \multicolumn{3}{|c|}{ Canine visceral leishmaniasis } & \multirow[b]{3}{*}{ OR } & \multirow[b]{3}{*}{$95 \% \mathrm{CI}$} & \multirow[b]{3}{*}{$\mathrm{P}$ value } \\
\hline & \multicolumn{2}{|c|}{ positive } & \multirow{2}{*}{$\frac{\text { negative }}{\mathrm{n}}$} & & & \\
\hline & $\mathrm{n}$ & $\%$ & & & & \\
\hline \multicolumn{7}{|l|}{ Aware of transmission } \\
\hline yes & 9 & 32.2 & 21 & 1 & $0.7462-5.442$ & 0.164 \\
\hline no & 19 & 67.8 & 22 & 2.015 & & \\
\hline \multicolumn{7}{|l|}{ Aware of human visceral leishmaniasis } \\
\hline yes & 27 & 96.4 & 39 & 2.769 & $0.293-26.158$ & 0.642 \\
\hline no & 1 & 3.6 & 4 & 1 & & \\
\hline \multicolumn{7}{|l|}{ Aware of the human symptoms ${ }^{¥}$} \\
\hline yes & 8 & 29.6 & 8 & 1.632 & $0.525-5.072$ & 0.395 \\
\hline no & 19 & 70.4 & 31 & 1 & & \\
\hline \multicolumn{7}{|l|}{ There is a cure for humans ${ }^{¥}$} \\
\hline yes & 14 & 51.8 & 21 & 0.923 & $0.345-2.467$ & 0.873 \\
\hline no & 13 & 48.2 & 18 & 1 & & \\
\hline \multicolumn{7}{|l|}{ There is a vaccine for humans ${ }^{¥}$} \\
\hline no & 3 & 11.1 & 7 & 0.571 & $0.134-2.442$ & 0.508 \\
\hline don't know & 24 & 88.9 & 32 & 1 & & \\
\hline \multicolumn{7}{|l|}{ Aware of canine visceral leishmaniasis } \\
\hline yes & 25 & 89.3 & 40 & 0.625 & $0.117-3.342$ & 0.674 \\
\hline no & 3 & 10.7 & 3 & 1 & & \\
\hline \multicolumn{7}{|l|}{ Aware of the canine symptoms ${ }^{¥}$} \\
\hline yes & 19 & 76.0 & 34 & 0.559 & $0.158-1.976$ & 0.513 \\
\hline no & 6 & 24.0 & 6 & 1 & & \\
\hline \multicolumn{7}{|l|}{ There is a cure for dogs ${ }^{¥}$} \\
\hline no & 10 & 40.0 & 27 & 1 & $1.103-8.801$ & 0.029 \\
\hline don't know & 15 & 60.0 & 13 & 3.115 & & \\
\hline \multicolumn{7}{|l|}{ There is a treatment for dogs ${ }^{\ddagger}$} \\
\hline don't know & 12 & 48.0 & 18 & 1.128 & $0.414-3.072$ & 0.813 \\
\hline euthanasia & 13 & 52.0 & 22 & 1 & & \\
\hline \multicolumn{7}{|l|}{ There is a canine vaccine $e^{¥}$} \\
\hline yes & 11 & 44.0 & 19 & 0.868 & $0.318-2.371$ & 0.783 \\
\hline no & 14 & 56.0 & 21 & 1 & & \\
\hline \multicolumn{7}{|l|}{ Preventive measure } \\
\hline don't know & 17 & 60.7 & 24 & 1 & - & - \\
\hline focused on the human and canine population & 0 & 0.0 & 2 & 0.28 & $0.012-6.206$ & 0.66 \\
\hline environmental handling and focused on the canine population & 2 & 7.1 & 2 & 1.41 & $0.18-11.04$ & 0.841 \\
\hline environmental handling and focused on the human population & 0 & 0.0 & 1 & 0.466 & $0.017-12.15$ & 0.844 \\
\hline focused on the canine population & 4 & 14.3 & 11 & 0.513 & $0.139-1.88$ & 0.366 \\
\hline environmental handling & 5 & 17.9 & 3 & 2.353 & $0.4941-11.21$ & 0.4397 \\
\hline
\end{tabular}

OR: odds ratio; 95\% CI: confidence interval 95\%; ${ }^{\ddagger}$ variables with no response by some respondents. 
The interviewees had very limited knowledge of the measures to prevent the disease, as observed in other surveys performed in the country ${ }^{18,22}$. Although there was no significant association with the CVL test results, these data remain relevant. Regarding the knowledge of prevention methods directed at the environment, humans or animals, measures such as proper environmental management with intra- and peri-domestic cleaning, the use of protective screens on doors and windows, repellents on the skin, insecticide sprays and insecticidal collars for $\operatorname{dog}^{23}$ could be implemented to enable the active participation of the population in the control and prevention of $\mathrm{VL}^{13}$.

\section{Factors associated with the reservoir}

Our results demonstrated less awareness of the symptoms of HVL compared to CVL, and similar data have been reported in surveys in Petrolina, in the State of Pernambuco, Brazil, which is another endemic VL region. There, $92 \%$ of the population interviewed could name the common symptoms of $\mathrm{CVL}^{5}$. Awareness of CVL is crucial because the disease is more common in dogs than in humans in urban areas ${ }^{4}$ and because the campaigns for controlling human disease are focused on the canine reservoir ${ }^{20,24}$.

Knowledge regarding the cure of CVL was a statistically significant factor associated with canine infection in the studied riverside areas. Thus, a lack of knowledge regarding a cure for CVL likely favors the continuation of the disease in these areas and also makes it more difficult for the population to agree to euthanize infected dogs to interrupt the epidemiological chain of the disease.

It is important to consider that, in most cases, canine infection precedes human cases of infection ${ }^{3,4,25}$. The detection of $L$. infantum DNA in the canine population is significant because these infections maintain the disease cycle for the human population; thus, dogs may serve as effective sentinels in these areas.

The interviewees were not aware of a vaccine to prevent HVL, which is significant, because no such vaccine exists. There was a similar lack of awareness for the vaccine used to prevent CVL, showing that this preventive measure is not widely used (although two vaccines are available in Brazil, Leishmune ${ }^{\circledR}$ and Leishtec $\left.{ }^{\circledR}\right)$. Indeed, the former vaccine has been available in the country since $2004^{26}$. The low rate of vaccination against CVL may be associated with the low income in the interviewed population.

The parasite was detected by PCR in the peripheral blood of dogs in the studied riverside areas. PCR has been performed for the diagnosis of CVL, with its potential for parasite detection showing high levels of sensitivity and specificity ${ }^{27}$, and no significant difference has been reported for samples obtained from canine peripheral blood, bone marrow, and skin fragments ${ }^{28}$.

The presence of CVL-positive dogs in Mossoró should concern local authorities because dogs are the primary domestic reservoir for human disease in urban areas ${ }^{29}$. Thus, the identification of infected dogs is important to interrupt the cycle of transmission in urban areas ${ }^{30}$. This interruption involves the euthanasia of infected dogs, according to the Surveillance Program and Visceral Leishmaniasis Control Program of the Ministry of Health in Brazil ${ }^{31}$.
The riverside populations interviewed in Mossoró have a low socioeconomic status and poor living conditions, and the low level of awareness regarding VL in this population was associated with canine infection. However, changes in habits and attitudes and the addition of preventive practices may contribute to the control and prevention of this disease. It is important to consider that a study evaluating only households with dogs could be biased, as the knowledge of the entire population is important for the prevention and control of CVL. Thus, future studies should address the knowledge of the general population.

This study reinforces the need for greater governmental investment in health education regarding VL. These programs should provide information on how to prevent transmission and subsequent outbreaks; in particular, such programs are particularly needed in areas near rivers and lakes (as in this study) to enable high-risk populations to participate actively in the prevention and control of this disease.

\section{ACKNOWLEDGMENTS}

We are grateful to the Director of the Health Surveillance of the City Hall of Mossoró, Rio Grande do Norte, Brazil, the Veterinarian Microbiology Laboratory at the Universidade Federal Rural do Semi-árido, and the Laboratory of Immunomodulation and Protozoology, Instituto Oswaldo Cruz, FIOCRUZ, Rio de Janeiro, Brazil.

\section{CONFLICT OF INTEREST}

The authors declare that there is no conflict of interest.

\section{REFERENCES}

1. World Health Organization: Leishmaniasis: background information. Available at: http://www.who.int/leishmaniasis/en/.

2. Ministério da Saúde. Manual de vigilância e controle da leishmaniose visceral. Secretaria de Vigilância em Saúde [Internet]. Brasília: Editora do Ministério da Saúde; 2006. [cited 2014 May 10]. Available at: http:// bvsms.saude.gov.br/bvs/publicacoes/manual_vigilancia_controle_ leishmaniose_visceral.pdf.

3. André WPP, Fonseca ZAAS, Ribeiro WLC, Bessa EN, Paiva KAR, Moura ESR, et al. Análise dos casos de leishmaniose humana e sua relação com a eutanásia de animais recolhidos pelo centro de controle de zoonoses de Mossoró-RN. Rev Bras Hig Sanid Anim 2013; 7: 212-224.

4. Goes MAO, Melo CM, Jeraldo VLS. Série temporal da leishmaniose visceral em Aracaju, estado de Sergipe, Brasil (1999 a 2008): aspectos humanos e caninos. Rev bras epidemiol 2012; 15:298-307.

5. Maia CS, Pimentel DS, Santana MA, Oliveira GM, Faustin MAG, Alves LC. The perception of the risk factors associated with american visceral leishmaniasis in Petrolina, Pernambuco, Brazil. Med Vet 2013; 7:19-25.

6. Schneider MC, Tirado MC, Rereddy S, Dugas R, Borda MI, Peralta EA, et al. Natural disasters and communicable diseases in the America: contribution of veterinary public health. Vet Ital 2012; 48:193-218.

7. Amóra SSA, Bevilaqua CML, Feijó FMC, Oliveira PGM, Peixoto GCX, Sousa RN, et al. Sandflies (Psychodidae: Phlebotominae) survey in an urban transmission area of visceral leishmaniasis, Northeastern Brazil. Rev Bras Parasitol Vet Jaboticabal 2010a; 19:233-237. 
8. Kalluri S, Gilruth P, Rogers D, Szczur M. Surveillance of arthropod vector-borne infectious diseases using remote sensing techniques: a review. PLoS Pathogens 2007; 3:e116.

9. Amóra SSA, Bevilaqua CML, Dias EC, Feijó FMC, Oliveira PGM, Peixoto GCX, et al. Monitoring of Lutzomyia longipalpis Lutz \& Neiva, 1912 in an area of intense transmission of visceral leishmaniasis in Rio Grande do Norte, Northeast Brazil. Rev Bras Parasitol Vet Jaboticabal 2010b; 19:39-43.

10. Koirala S, Parija SC, Karki P, M.L. Das ML. Knowledge, attitudes, and practices about kala- azar and its sandfly vector in rural communities of Nepal. Bull World Health Organ 1998; 76:485-490.

11. Esch KJ, Pontes NN, Arruda P, O'Connor A, Morais L, Jeronimo SMB, et al. Preventing Zoonotic Canine Leishmaniasis in Northeastern Brazil: Pet Attachment and Adoption of Community Leishmania Prevention. Am J Trop Med Hyg 2012, 87:822-831.

12. Alemu A, Alemu A, Esmael N, Dessie Y, Hamdu K, Mathewos B, et al. Knowledge, attitude and practices related to visceral leishmaniasis among residents in Addis Zemen town, South Gondar, Northwest Ethiopia. BMC Public Health 2013; 13:382.

13. Borges BKA, Silva JA, Haddad JPA, Moreira EC, Magalhães DF, Ribeiro LML, et al. Asscessment of knowledge and preventive attitudes concerning visceral leishmaniasis in Belo Horizonte, Minas Gerais State, Brazil. Cad Saude Publica 2008; 24:777-784.

14. Instituto Brasileiro de Geografia e Estatística (IBGE) [Internet]. Cidades. Brasília: IBGE. 2013 - [cited 2014 Mai 10]. Available at: http:// cod.ibge.gov.br/232UO.

15. Secretaria de Estado do Planejamento e das Finanças. Governo do Estado do Rio Grande do Norte. Perfil do Rio Grande do Norte. 2014 - [Cited 2014 Mai 10]. Available at: http://www.seplan.rn.gov.br/ arquivos/download/PERFIL\%20DO\%20RN\%202014.pdf/.

16. Leite AI, Araújo LB. Leishmaniose visceral: aspectos epidemiológicos relacionados aos óbitos em Mossoró-RN. Rev Patol Trop 2013; 42: 301-308.

17. Harris E, Kropp G, Belli A, Rodriguez B, Agabian N. Single-step multiplex PCR assay for characterization of new world Leishmania complexes. J Clin Microbiol 1998; 36:1989-1995.

18. Margonari C, Menezes JA, Rocha MN, Maia KN, Eder de Oliveira M, Luisa Fonseca A, et al. Public knowledge about and detection of canine visceral leishmaniasis in urban Divinópolis, Brazil. J Trop Med 2012; ID429586.

19. Lobo KS, Bezerra JMT, Brito LMO, Silva JS, Pinheiro VCS. Conhecimentos de estudantes sobre leishmaniose visceral em escolas públicas de Caxias, Maranhão, Brasil. Ciênc Saude Coletiva 2013; 18:2295-2300.

20. Queiroz MFM, Varjao JR, Moraes SC, Salcedo GE. Analysis of sandflies (Diptera: Psychodidae) in Barra do Garças, State of
Mato Grosso, Brazil, and the influence of environmental variables on the vector density of Lutzomyia longipalpis (Lutz \& Neiva, 1912). Rev Soc Bras Med Trop 2012; 45:313-317.

21. Barata RA, Peixoto JC, Tanure A, Gomes ME, Apolinário EC, Bodevan EC, et al. Epidemiology of visceral leishmaniasis in a reemerging focus of intense transmission in Minas Gerais State, Brazil. Hindawi Publishing Corporation. Biomed Res Int 2013; ID405083.

22. Santos JB, Lauand L, Souza GS, Macêdo VO. Socioeconomic factors and attitudes towards household prevention of american cutaneous leishmaniasis in an endemic area in Southern Bahia, Brazil. Cad Saude Publica 2000; 16:701-708.

23. Coura-Vital W, Reis AB, Fausto MA, Leal GGDA, Marques MJ, Veloso VM, et al. Risk factors for seroconversion by Leishmania infantum in a cohort of dogs from an endemic area of Brazil. PLoS One 2013; 8:e71833.

24. Picado A, Ostyn B, Singh SP, Uranw S, Hasker E, Rijal S, et al. Risk factors for visceral leishmaniasis and asymptomatic Leishmania donovani infection in India and Nepal. PLoS One 2014; 9:87641; doi:10.1371/journal.pone.0087641.

25. Araujo VEM, Pinheiro LC, Mattos Almeida MC, Menezes FC, Morais MHF, Reis IA, et al. Relative risk of visceral leishmaniasis in Brazil: a spatial analysis in urban area. PLoS Negl Trop Dis 2013; 7:e2540.

26. Amorim IF, Freitas E, Alves CF, Tafuri WL, Melo MN, Michalick MS. Humoral immunological profile and parasitological statuses of Leishmune ${ }^{\circledR}$ vaccinated and visceral leishmaniasis infected dogs from an endemic area. Vet Parasitol 2010; 173:55-63.

27. Costa LNG, Borba AS, Castagna CL, Carvalho Filho EB, Marson FAL, Sá Junior FF, et al. Evaluation of PCR in the diagnosis of canine leishmaniasis in two different epidemiological regions: Campinas (SP) and Teresina (PI), Brazil. Epidemiol Infect 07/2014; DOI: 10.1017/50950268814001721

28. Mohammadiha A, Haghighi A, Mohebali M, Mahdian R, Abadi AR, Zarei Z, et al. Canine visceral leishmaniasis: a comparative study of real-time PCR, conventional PCR, and direct agglutination on sera for the detection of Leishmania infantum infection. Vet Parasitol 2013, 18:192:83-90

29. Prado PF, Rocha MF, Sousa JF, Caldeira DI, Paz GF, Dias ES. Epidemiological aspects of human and canine visceral leishmaniasis in Montes Claros, State of Minas Gerais, Brazil, between 2007 and 2009. Rev Soc Bras Med Trop 2011; 44:561-566.

30. Braga AR, Langoni H, Lucheis SB. Evaluation of canine and feline leishmaniasis by the association of blood culture, immunofluorescent antibody test and polymerase chain reaction. J Venom Anim Toxins Incl Trop Dis 2014; 20:5.

31. Barbosa DS, Belo VS, Rangel MES, Werneck GL. Spatial analysis for identification of priority areas for surveillance and control in a visceral leishmaniasis endemic area in Brazil. Acta Trop 2014; 131:56-62. 